\title{
New records of Pisidium tenuilineatum Stelfox, 1918 (Bivalvia, Sphaeriidae) from Slovakia
}

\author{
LUBOŠ BERAN ${ }^{1} \&$ TOMÁŠ Č́EJKA ${ }^{2}$ \\ ${ }^{I}$ Nature Conservation Agency of the Czech Republic, Regional Office Kokořinsko - Máchiov kraj Protected Landscape Area \\ Administration, Česká 149, CZ-27601 Mělník, Czech Republic, e-mail: lubos.beran@nature.cz, \\ (1D) https://orcid.org/0000-0002-5851-6048 \\ ${ }_{2}^{2}$ Institute of Botany, Plant Science and Biodiversity Center, Slovak Academy of Sciences, Dúbravská cesta 9, SK-84523 Bratislava, \\ Slovak Republic, e-mail: t.cejka@gmail.com, (1) https://orcid.org/0000-0002-6485-5660
}

Beran L. \& ČejKa T., 2019: New records of Pisidium tenuilineatum Stelfox, 1918 (Bivalvia, Sphaeriidae) from Slovakia. - Malacologica Bohemoslovaca, 18: 15-18. Online serial at <http://mollusca.sav.sk> 1-Nov-2019.

So far, Pisidium tenuilineatum has been reported from Slovakia only from four sites. Six new sites of this pea mussel have been found during the last twenty years in Slovakia in both small karstic watercourses (e.g. rivulets, brooks and small rivers) and large lowland rivers. These new records show that $P$. tenuilineatum should be still considered as a rare species in Slovakia but some new populations are still likely to be discovered especially in lower elevations and in the areas of low anthropogenic influence.

Key words: Mollusca, Bivalvia, Pisidium tenuilineatum, new records, Slovakia

\section{Introduction}

Pisidium tenuilineatum (Fig. 1) is widely distributed across the western Palearctic from the Mediterranean to southern Sweden and eastwards to European part of Russia (ŽADIN 1952, Killeen \& Seddon 2011, Welter-Schultes 2012, VINARSKI \& KANTOR 2016). Its distribution is scattered in many countries and because it even declines in Europe, it was listed in the IUCN Red List in the category Least Concern (KILLEEN \& SEDDON 2011). This species is Red listed in several European countries and belongs to rare and declining species. Fine-lined pea mussel was listed as Critically Endangered in the Red List in Slovakia (ŠTEFFEK \& VAVRová 2006).

This species was recorded in Slovakia for the first time in 1955 from a karstic pond and small rivulet near the town of Košice (LožEK 1956, 4845'12.5"N, 21 $\left.{ }^{\circ} 12^{\prime} 56.2^{\prime \prime} \mathrm{E}\right)$. The same author found this species also nearly 20 years later near the village of Súl'ov (LožEK 1974, 49¹0'09.3"N, $\left.18^{\circ} 36^{\prime} 02.9^{\prime \prime E}\right)$. Other records were reported from the Izra Lake (LisıckÝ 1991, lgt. J. Brabenec, 48³4'12.2"N, $\left.21^{\circ} 29^{\prime} 38.6^{\prime \prime E}\right)$ and from underground brooks near the Silica Plateau (GULIČKA 1975, 48³4'13.6"N, 20²9'44.2"E) (Fig. 2). Except the latter one, all these historical data were summarized in LISICKÝ (1991). Recently, more data about the species occurrence in Slovakia have been obtained and are summarized in this paper.

\section{Material and methods}

Data were obtained during field malacological surveys. The main sampling method for aquatic molluscs applied also for this research is washing vegetation or sediments using a metal sieve (diameter $20 \mathrm{~cm}, 0.8 \mathrm{~mm}$ mesh) combined with collections by hand with searching on surfaces of stones, woods and artificial material (e.g. plastic bags and bottles). This species and other small bivalves were obtained mostly by washing sediments using the sieve. Freshwater molluscs were identified using shell characteristics (most species, including $P$. tenuilineatum) or dissected and then identified using their copulatory organs if the identification only based on shells was impossible. Selected material of shells of $P$. tenuilineatum is deposited in the authors' collections and M. Horsák's collection (Brno).

\section{Results}

Altogether six new sites with the occurrence of this rare species have been found during the last twenty years in Slovakia (Fig. 2).

1 - 48 $19^{\prime} 23.4^{\prime \prime} \mathrm{N}, 17^{\circ} 04^{\prime} 35.4^{\prime \prime E}$, Lozorno, a small brook ca. $700 \mathrm{~m}$ upstream of its inflow into the dam water reservoir, $232 \mathrm{~m}$ a. s. 1., 4 live specimens, 6 empty shells, lgt. \& det. T. Čejka, 15. 5. 2010;

$2-48^{\circ} 56^{\prime} 45.5^{\prime \prime} \mathrm{N}, 17^{\circ} 54^{\prime} 48.5^{\prime \prime} \mathrm{E}$, Liešna, the Drietomica Brook, $323 \mathrm{~m}$ a. s. 1., 1 live specimen, lgt. K. Brabec, det. \& coll. M. Horsák, 11. 7. 2000;

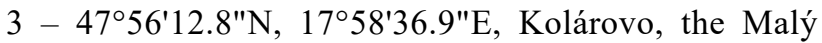
Dunaj River branch, $111 \mathrm{~m}$ a. s. 1., 2 live specimens, lgt. \& det. T. Čejka, 18. 9. 2003;

$4-48^{\circ} 47^{\prime} 37^{\prime \prime N}, 18^{\circ} 20^{\prime} 51.1^{\prime \prime E}$, Kšinná, the Radiša Brook, $305 \mathrm{~m}$ a. s. 1., 1 live specimen, lgt. S. Ščerbáková, det. T. Čejka, 24. 6. 2010;

$5-49^{\circ} 01^{\prime} 49.8^{\prime \prime N}, 18^{\circ} 53^{\prime} 53.6^{\prime \prime E}$, Košt'any nad Turcom, the Turiec River by the bridge (Fig. 3), $415 \mathrm{~m}$ a. s. 1., 15 live specimens, lgt. \& det. L. Beran, 30. 6. 2017;

$6-49^{\circ} 05^{\prime} 04.5^{\prime \prime} \mathrm{N}, 19^{\circ} 21^{\prime} 20.5^{\prime \prime} \mathrm{E}$, Lisková, the Váh River, $485 \mathrm{~m}$ a. s. 1., 3 empty shells, lgt. E. Mišíková-Elexová, det. T. Čejka, 2010. 


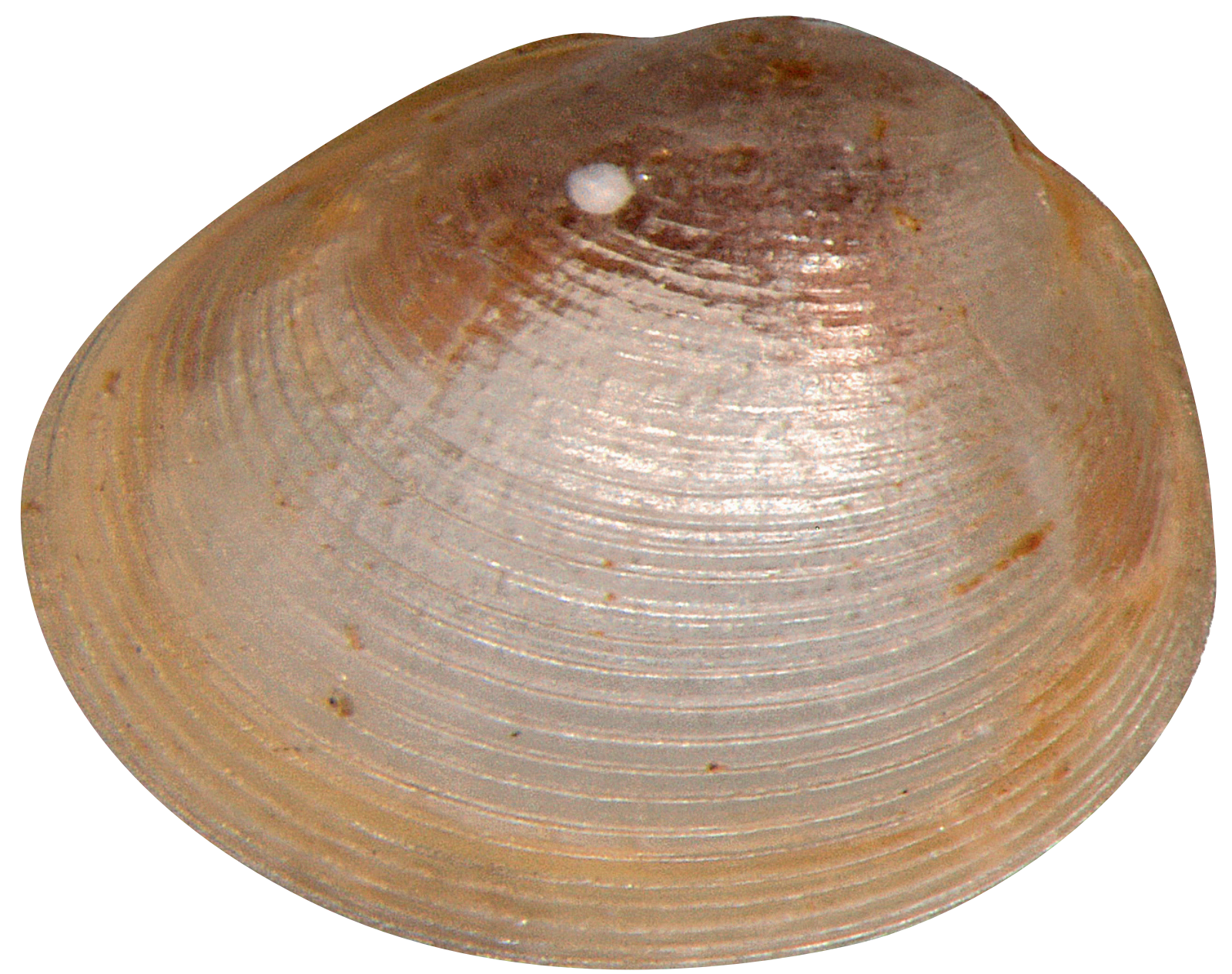

Fig. 1. Pisidium tenuilineatum. Photo by M. Horsák.

All these records were obtained from the western part of Slovakia. Four new records came from smaller brooks and rivers while two more findings were conducted in larger watercourses with a width of about $50 \mathrm{~m}$ (site No. 3 and 6). In the case of the Malý Dunaj River branch, co-occurrence of 22 species was confirmed, while in the other sites co-occurrence of 2-7 species was documented (Tab. 1). Pisidium tenulineatum co-occurred with other sensitive or endangered molluscs in the Turiec River (Unio crassus, Pisidium amnicum) and Malý Dunaj River branch (e.g. Theodoxus danubialis, Borysthenia naticina, P. amnicum) (Tab. 1). The Turiec River was visited also in 2019 at the village of Socovce, ca. $12 \mathrm{~km}$ upstream of the site No. 5. The occurrence of $P$. tenuilineatum was not confirmed. Nearly in all cases, this pea mussel occurred in shallow parts of watercourses with fine sediment.

\section{Discussion}

Pisidium tenuilineatum inhabits in Slovakia both small karstic watercourses (rivulets, brooks, and small rivers) and large lowland rivers, while in the Czech Republic it is known from small rivers and brooks with a low anthropogenic influence (BERAN \& HoRSÁK 2001, BERAN 2016). In Great Britain species lives principally in clean, calcareous, unpolluted lowland rivers, large streams and occasionally also in ponds (Killen \& Seddon 2011). In Poland PieCHOCKI \& WAWRZYNIAK-WYDROWSKA (2016) mentioned that the species is mainly associated with small rivers where it stays on sandy or clayey bottom.

New records showed that $P$. tenuilineatum should be still considered as a rare species in Slovakia. This situation is similar to the Czech Republic (BERAN \& Horsák 2001, BERAN 2002, 2016) or Poland (PIECHOCKI \& WAWrzYNIAK-WydrowsKa 2016), while e.g. in Great Britain this species is more common as was considered during more detailed research (KILLEEN \& WILLING 2004). It is probable that in the case of more detailed research, some new sites with the occurrence of this rare pea mussel will be find also in Slovakia, especially in low elevations and in the areas with low anthropogenic influence. The more detailed research of adjacent parts of watercourses with the recent occurrence (e.g. Turiec River, Drietomica Brook, Radiša Brook) and also a revision of historical sites is needed.

\section{Acknowledgements}

Authors thank Michal Horsák for the photo of $P$. tenuilineatum and providing a record of $P$. tenuilineatum from the Drietomica Brook and Jan Vrba for drawing a map. 


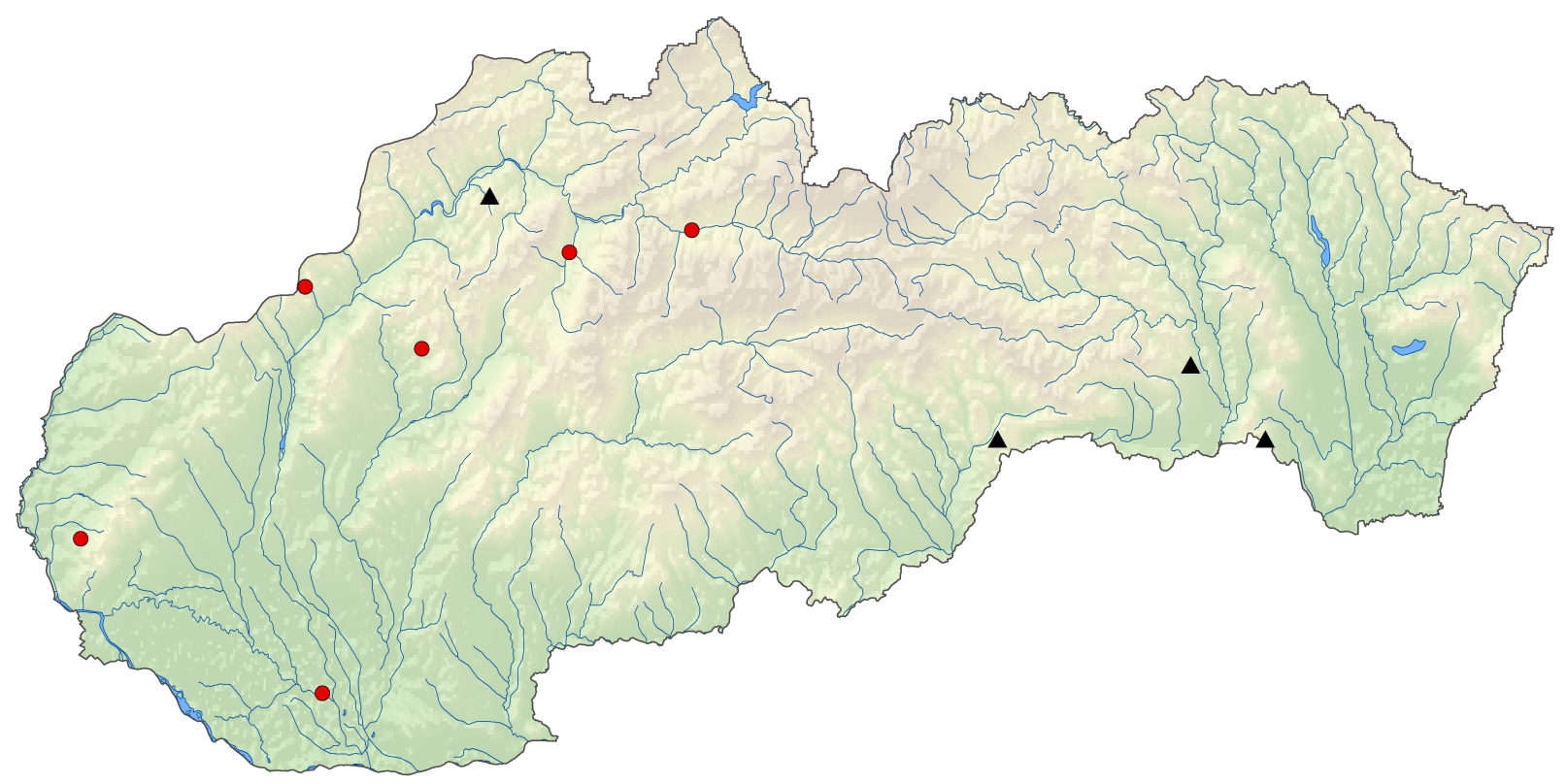

Fig. 2. Distribution of Pisidium tenuilineatum in Slovakia: black triangles - historical records, red circles - new records. Drawn by J. Vrba. Data source: C GADM 2015, (C NCA CR 2019.

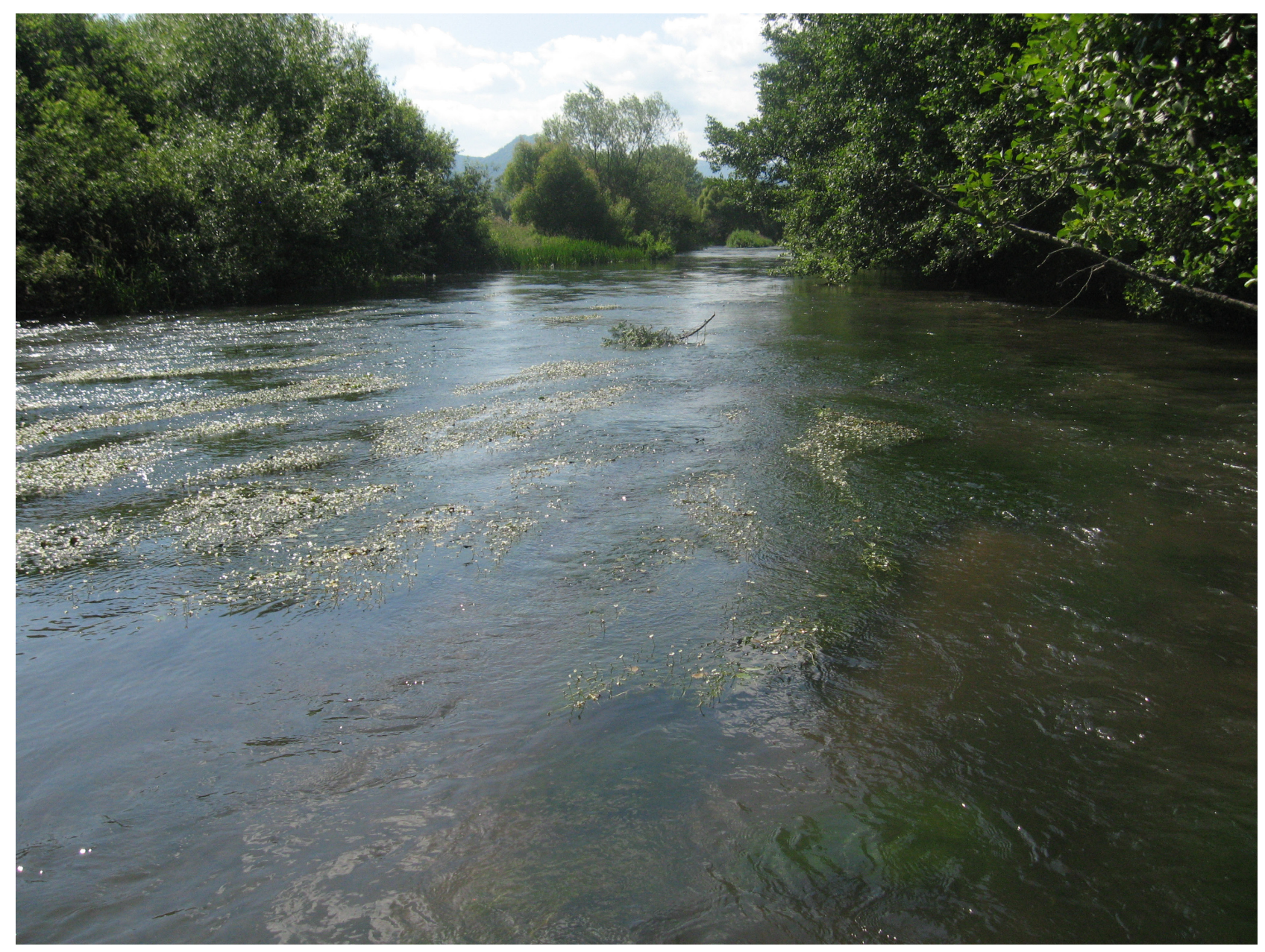

Fig. 3. The Turiec River (site no. 5). Photo by L. Beran. 


\section{References}

Beran L., 2002: Vodní měkkýši České republiky - rozšíření a jeho změny, stanoviště, širrení, ohrožení a ochrana, červený seznam [Aquatic molluses of the Czech Republic - distribution and its changes, habitats, dispersal, threat and protection, Red List]. - Sborník přírodovědného klubu v Uh. Hradišti, Supplementum 10, 258 pp. (in Czech).

BERAN L., 2016: Př́íspěvek k poznání vodních měkkýšů Ploučnice a její nivy mezi Českou Lípou a Mimoní [A contribution to the knowledge of aquatic molluscs of the Ploučnice River between the town of Česká Lípa and Mimoň]. - Malacologica Bohemoslovaca, 15: 21-29. (in Czech).

GULIČKA J., 1975: Fauna slovenských jaskýň [Fauna of Slovak caves]. - Slovenský kras, 13: 37-85. (in Slovak).

Killeen I. \& Seddon M. B., 2011: Pisidium tenuilineatum. - The IUCN Red List of Threatened Species 2011: e.T155679A4822037, accessed October 3, 2019.

KILLEEN I. J. \& WiLLING M. J., 2004: Further surveys to elucidate the distribution of the fine-lined pea mussel Pisidium tenuilineatum Stelfox, 1918. - Environment Agency Technical Report W1-054/TR. Environment Agency, Bristol.

LisıckÝ M. J., 1991: Mollusca Slovenska [Mollusca of Slovakia]. - Veda, Bratislava, 344 pp. (in Slovak).
LožEK V., 1956: Malakozoologické novinky z ČSR. III [Malacozoological news from Czechoslovakia. III]. - Časopis Národního musea, Oddíl př́rodovědný, 125, 2: 142-151. (in Czech). Piechocki A. \& WaWrzyniak-Wydrowska B., 2016: Guide to Freshwater and Marine Mollusca of Poland. - Bogucki Wydawnictvo Naukove, Poznań, 279 pp.

ŠTEFFEK J. \& VAVRová L'., 2006: Current ecosozological status of molluscs (Mollusca) of Slovakia in accordance with categories and criterion of IUCN - version 3.1. (2001). - In: Molluscs: Perspective of Development and Investigation, KYRYCHUK G. Y. (ed.) 27-29th September 2006, Zytomyr, Ukraine, 266-276.

VinARSKi M. \& KANTOR Y., 2016: Analytical catalogue of fresh and brackish water molluscs of Russia and adjacent countries. - A.N.Severtsov Institute of Ecology and Evolution of RAS, Moscow, 544 pp.

Welter-Schultes F. W., 2012: European non-marine molluscs, a guide for species identification. - Planet Poster Editions, Göttingen. 757 pp.

ŽADIN V. I., 1952: Moljuski presnych i solonovatych vod SSSR [Molluscs of freshwater and saltwater of USSR]. - Izd. AN SSSR, Moskva-Leningrad, 376 pp. (in Russian).

Table 1. The list of aquatic molluscs recorded at particular sites.

\begin{tabular}{|c|c|c|c|c|c|c|}
\hline Species/Site No. & 1 & 2 & 3 & 4 & 5 & 6 \\
\hline Theodoxus danubialis (C. Pfeiffer, 1828) & & & $\mathrm{x}$ & & & \\
\hline Viviparus acerosus (Bourguignat, 1862) & & & $\mathrm{x}$ & & & \\
\hline Bithynia tentaculata (Linnaeus, 1758) & & & $\mathrm{x}$ & & & \\
\hline Potamopyrgus antipodarum (Gray, 1843) & & & $\mathrm{x}$ & & & \\
\hline Lithoglyphus naticoides (C. Pfeiffer, 1826) & & & $\mathrm{x}$ & & & \\
\hline \multicolumn{7}{|l|}{ Valvata cristata O. F. Müller, 1774} \\
\hline Valvata piscinalis (O. F. Müller, 1774) & & & $\mathrm{x}$ & & & \\
\hline Borysthenia naticina (Menke, 1845) & & & $\mathrm{x}$ & & & \\
\hline Galba truncatula (O. F. Müller, 1774) & $\mathrm{x}$ & & & & & $\mathrm{x}$ \\
\hline Stagnicola cf. palustris (O. F. Müller, 1774) & & & $\mathrm{x}$ & & & $\mathrm{x}$ \\
\hline Radix ampla (Hartmann, 1821) & & & & & $\mathrm{x}$ & \\
\hline Radix auricularia (Linnaeus, 1758) & & & $\mathrm{x}$ & & & \\
\hline Radix balthica (Linnaeus, 1758) & & & $\mathrm{x}$ & & & $\mathrm{x}$ \\
\hline Radix labiata (Rossmäessler, 1835) & & & & $\mathrm{x}$ & & \\
\hline Lymnaea stagnalis (Linnaeus, 1758) & & & $\mathrm{x}$ & & & \\
\hline Ancylus fluviatilis O. F. Müller, 1774 & & & $\mathrm{x}$ & $\mathrm{x}$ & & $\mathrm{x}$ \\
\hline Unio pictorum (Linnaeus, 1758) & & & $\mathrm{x}$ & & & \\
\hline Unio crassus Philipsson, 1788 & & & & & $\mathrm{x}$ & \\
\hline Anodonta anatina (Linnaeus, 1758) & & & $\mathrm{x}$ & & & \\
\hline Corbicula fluminea (O. F. Müller, 1774) & & & $\mathrm{x}$ & & & \\
\hline Sphaerium corneum (Linnaeus, 1758) & & & $\mathrm{x}$ & & $\mathrm{x}$ & $\mathrm{x}$ \\
\hline Sphaerium rivicola (Lamarck, 1818) & & & $\mathrm{x}$ & & & \\
\hline Musculium lacustre (O. F. Müller, 1774) & & & $\mathrm{x}$ & & & \\
\hline Pisidium amnicum (O. F. Müller, 1774) & & & $\mathrm{x}$ & & $\mathrm{x}$ & \\
\hline Pisidium casertanum (Poli, 1791) & $\mathrm{x}$ & $\mathrm{x}$ & & $\mathrm{x}$ & & $\mathrm{x}$ \\
\hline Pisidium henslowanum (Sheppard, 1823) & & & $\mathrm{x}$ & & & \\
\hline Pisidium personatum Malm, 1855 & $\mathrm{x}$ & $\mathrm{x}$ & & $\mathrm{x}$ & & \\
\hline Pisidium subtruncatum Malm, 1855 & $\mathrm{x}$ & & & & $\mathrm{x}$ & $\mathrm{x}$ \\
\hline Pisidium supinum A. Schmidt, 1851 & & & $\mathrm{x}$ & & & \\
\hline Pisidium tenuilineatum Stelfox, 1918 & $\mathrm{x}$ & $\mathrm{x}$ & $\mathrm{x}$ & $\mathrm{x}$ & $\mathrm{x}$ & $\mathrm{x}$ \\
\hline Dreissena polymorpha (Pallas, 1771) & & & $\mathrm{x}$ & & & \\
\hline Number of species & 5 & 3 & 23 & 5 & 6 & 8 \\
\hline
\end{tabular}

